\title{
ANALISIS PENGARUH RASIO LIKUIDITAS, SOLVABILITAS, PROFITABILITAS, DAN AKTIVITAS TERHADAP NILAI PERUSAHAAN PADA PERUSAHAAN YANG TERGabUNG DALAM INDEKS LQ45 DI BURSA EFEK INDONESIA PERIODE 2012 - 2015
}

\section{Bistok Simorangkir dan Nunung Nurhasanah}

Fakultas Ekonomi dan bisnis Universitas Singaperbangsa Karawang

Email: 1910632020054@student.unsika.ac.id dan nunungnurhasanah@feb.unsika.ac.id

\begin{abstract}
Abstrack
The purpose of this study is to determine whether the company's performance is good or bad, to know how much the Liquidity Ratio, Solvency, Profitability, Activity, and Market have an effect on Firm Value in companies that are members of the LQ45 stock index on the Indonesian Stock Exchange 2012-2015. In this study, the authors using this type of qualitative research method as a research method based on the philosophy of postpositivism, used to examine the condition of natural objects, where the researcher is the key instrument, the data collection technique is done by triangulation (combined), the data analysis is inductive / qualitative. The data used as the research object comes from secondary data taken from the main source (company), namely by downloading the data on the website www.idx.co.id. is a data collection technique by means of documentation. Return on Assets has a negative and insignificant effect on the Firm Value (Price to Book Value) because the probability value of -0.162225 is less than the value of $\alpha$ (0.05) or not significant. Total Assets Turnover has a positive and significant effect on Firm Value (Price to Book Value) because the probability value is $0.0407<\alpha(0.05)$.
\end{abstract}

Keywords: liquidity ratios; solvency; profitability; activities

\section{Abstrak}

Tujuan penelitian ini adalah Untuk mengetahui baik buruknya kinerja perusahaan, mengetahui seberapa besar Rasio Likuiditas, Solvabilitas, Profitabilitas, Aktivitas, dan Pasar berpengaruh terhadap Nilai Perusahaan pada perusahaan yang tergabung dalam indeks saham LQ45di Bursa Efek Infonesia periode 2012 -2015. Dalam penelitian ini, penulis menggunakan jenis metode penelitian kualitatif sebagai metode penelitian yang berlandaskan pada filsafat postpositivisme, digunakan untuk meneliti pada kondisi obyek yang alamiah, dimana peneliti sebagai instrumen kunci, teknik pengumpulan data dilakukan secara triangulasi (gabungan), analisis data bersifat induktif/kualitatif. Data yang dijadikan obyek penelitian berasal dari data sekunder yang diambil dari bkan dari sumber utama (perusahaan) yaitu dengan cara mengunduh data di website www.idx.co.id. merupakan teknik pengumpulan data dengan cara dokumentasi. Return on Assets berpengaruh negatif tidak signifikan terhadap Nilai Perusahaan (Price to Book Value)) karena nilai probabilitasnnya 
Analisis Pengaruh Rasio Likuiditas, Solvabilitas, Profitabilitas, dan Aktivitas terhadap Nilai Perusahaan pada Perusahaan yang Tergabung dalam Indeks Lq45 di Bursa Efek Indonesia Periode 2012 - 2015

sebesar sebesar $-0,162225$ lebih kecil dari nilai $\alpha(0,05)$ atau tidak signifikan. Total Assets Turnover berpengaruh positif dan signifikan terhadap Nilai Perusahaan (Price to Book Value) karena nilai probabilitasnnya sebesar $0,0407<$ nilai $\alpha(0,05)$.

Kata kunci: rasio likuiditas; solvabilitas; profitabilitas; aktivitas

\section{Pendahuluan}

Dalam perkembangan suatu perusahaan, perlu untuk memaksimalkan nilai perusahaan yang dapat dicapai melalui pelaksanaan fungsi manajemen keuangan, dimana satu keputusan keuangan yang diambil akan mempengaruhi keputusan keuangan lainnya dan berdampak pada nilai perusahaan (Fama \& French, 1998). Menurut (Hasnawati, 2005), manajemen keuangan menyangkut penyelesaian atas keputusan penting yang diambil perusahaan, antara lain keputusan investasi, keputusan pendanaan, dan kebijakan dividen. Suatu kombinasi yang optimal atas ketiganya akan memaksimumkan nilai perusahaan yang selanjutnya akan meningkatkan kemakmuran kekayaan pemegang saham. Nilai perusahaan sangat penting karena mencerminkan kinerja perusahaan yang dapat mempengaruhi persepsi investor terhadap perusahaan. Nilai perusahaan sangat penting karena dengan nilai perusahaan yang tinggi akan diikuti oleh tingginya kemakmuran pemegang saham. Semakin tinggi harga saham semakin tinggi pula nilai perusahaan. Nilai perusahaan yang tinggi merupakan keinginan para pemilik perusahaan, sebab dengan nilai yang tinggi menunjukkan kemakmuran pemegang saham yang tinggi juga. Kekayaan pemegang saham dan perusahaan dipresentasikan oleh harga pasar dari saham yang merupakan cerminan dari keputusan investasi pendanaan (financing) dan manajemen asset (Susanti \& Pangestuti, 2010). Nilai perusahaan akan tercermin dari harga sahamnya. Harga pasar dari saham perusahaan yang terbentuk antara pembeli dan penjual disaat terjadi transaksi disebut nilai pasar perusahaan, karena harga pasar saham dianggap cerminan dari nilai aset perusahaan sesungguhnya. Nilai perusahaan yang dibentuk melalui indikator nilai pasar saham sangat dipengaruhi oleh peluang-peluang investasi. Adanya peluang investasi dapat memberikan sinyal positif tentang pertumbuhan perusahaan dimasa yang akan datang, sehingga dapat meningkatkan nilai perusahaan.

Nilai perusahaan dalam penelitian ini didefinisikan sebagai nilai pasar, seperti halnya penelitian yang pernah dilakukan oleh (Nurlela, 2008). Karena nilai perusahaan dapat memberikan kemakmuran pemegang saham secara maksimum apabila harga saham perusahaan meningkat. Semakin tinggi harga saham, maka makin tinggi kemakmuran pemegang saham, untuk mencapai nilai perusahaan umumnya para pemodal menyerahkan pengelolaannya kepada para professional. Para professional diposisikan sebagai manajer ataupun komisaris (Kusumadilaga, 2010). Menurut (Nurlela, 2008; Samuel, Found, \& Williams, 2015) menjelaskan bahwa enterprise value (EV) atau dikenal juga sebagai firm value (nilai perusahaan) merupakan konsep penting bagi investor, karena merupakan indikator bagi pasar menilai perusahaan secara keseluruhan. (Nurlela, 2008) menyebutkan bahwa nilai perusahaan merupakan harga yang bersedia dibayar oleh calon pembeli andai perusahaan tersebut dijual. Perusahaan 
dengan struktur modal yang tidak baik dan hutang yang sangat besar akan memberikan beban berat kepada perusahaan sehingga perlu diusahakan suatu keseimbangan yang optimal dalam menggunakan kedua sumber tersebut sehingga dapat memaksimalkan nilai perusahaan. Semakin tingginya modal suatu perusahaan yang berasal dari modal sendiri, baik investor maupun pemilik mengindikasikan rendahnya hutang yang dimiliki, sehingga cenderung akan memberikan insentif yang lebih besar kepada pemiliknya, yang akhirnya dapat mendorong tingginya pembayaran hasil investasi, di mana pada ujungnya akan meningkatkan nilai perusahaan dari naiknya harga saham.Di samping itu, perusahaan yang mempunyai tingkat likuiditas yang tinggi mengindikasikan kesempatan bertumbuh perusahaan cenderung tinggi. Semakin likuid perusahaan, maka semakin tinggi tingkat kepercayaan kreditur dalam memberikan dananya, sehingga dapat meningkatkan nilai perusahaan di mata kreditur maupun pada calon investor. Ukuran perusahaan dinilai mampu mempengaruhi nilai perusahaan. Semakin besar ukuran perusahaan maka akan semakin mudah pula perusahaan memperoleh sumber pendanaan baik yang bersifat internal maupun eksternal, sehingga perusahaan cenderung memiliki sumber dana yang lebih banyak guna menunjang kegiatan operasionalnya. Sehingga perusahaan dapat lebih banyak mendapatkan peluang memperoleh laba yang lebih tinggi. Dengan semakin tingginya perolehan laba akan meningkatkan harga saham perusahaan yang pada ujungnya akan meningkatkan nilai perusahaan.Penelitian yang telah dilakukan pada pasar modal di Indonesia yang banyak diilhami oleh penelitian-penelitian terdahulu seperti menurut (Hasnawati, 2005), fenomena yang terjadi di Bursa Efek Indonesia menunjukkan bahwa nilai perusahaan yang diproksi melalui nilai pasar saham mengalami perubahan meskipun tidak ada kebijakan keuangan yang dilakukan perusahaan. Nilai perusahaan berubah lebih disebabkan oleh informasi lain seperti situasi sosial dan politik. Menurut (Sudarma, 2004), faktor-faktor yang mempengaruhi nilai perusahaan adalah ukuran perusahaan, pertumbuhan perusahaan, keunikan perusahaan, nilai aktiva, deviden, penghematan pajak, struktur modal, fluktuasi nilai tukar, dan kedaan pasar modal. Sedangkan menurut Amirya dan (Achmad, Subekti, \& Atmini, 2007) dan (Oktaviani \& Puspitawati Haryadi, 2008), faktor-faktor yang mempengaruhi nilai perusahaan adalah kebijakan deviden, profitabilitas, pertumbuhan penjualan, dan ukuran perusahaan. Akan tetapi, dalam penelitian ini hanya dibahas dua faktor yang mempengaruhi nilai perusahaan, yaitu profitabilitas dan kebijakan deviden. Rumusan masalah dalam penelitian ini yaitu perlu untuk mengadakan penelitian mengenai pengaruh rasio keuangan terhadap nilai perusahaan dalam perusahaan yang terdaftar dalam indeks saham LQ45 di Bursa Efek Indonesia. Oleh karena itu dalam memakmurkan kepentingan stakeholder untuk mencapai nilai perusahan yang maksimal, maka permasalahan ini merupakan hal yang menarik untuk dijadikan bahan penelitian dalam penulisan tesis ini. Apakah Rasio Likuiditas,Solvabilitas, Profitabilitas dan Aktivitas berpengaruh secara simultan maupun parsial terhadap Nilai Perusahaan pada perusahaan yang tergabung dalam indeks LQ45 di Bursa Efek Infonesia periode 2015 2015? dan seberapa besar pengaruh Rasio Likuiditas, Solvabilitas, Profitabilitas dan 
Analisis Pengaruh Rasio Likuiditas, Solvabilitas, Profitabilitas, dan Aktivitas terhadap Nilai Perusahaan pada Perusahaan yang Tergabung dalam Indeks Lq45 di Bursa Efek Indonesia Periode 2012 - 2015

Aktivitas terhadap Nilai Perusahaan pada perusahaan baik secara simultan maupun parsial. Tujuan penelitian ini adalah Untuk mengetahui baik buruknya kinerja perusahaan, mengetahui seberapa besar Rasio Likuiditas, Solvabilitas, Profitabilitas, Aktivitas, dan Pasar berpengaruh terhadap Nilai Perusahaan pada perusahaan yang tergabung dalam indeks saham LQ45 di Bursa Efek Infonesia periode 2012 -2015

\section{Metode Penelitian}

Dalam penelitian ini, penulis menggunakan jenis metode penelitian kualitatif sebagai metode penelitian yang berlandaskan pada filsafat postpositivisme, digunakan untuk meneliti pada kondisi obyek yang alamiah, dimana peneliti sebagai instrumen kunci, teknik pengumpulan data dilakukan secara triangulasi (gabungan), analisis data bersifat induktif/kualitatif. Metode penelitian yang akan digunakan dalam penelitian ini adalah metode deskriptif dan verifikatif, karena adanya variabel-variabel yang akan ditelaah hubungannya serta tujuannya untuk menyajikan gambaran secara terstruktur, faktual, dan akurat mengenai fakta-fakta serta hubungan antar variabel yang diteliti, yaitu pengaruh Cash Ratio, Debt to Equity Ratio dan Return on Equity terhadap nilai perusahaan dengan kebijakan dividen sebagai variabel intervening (mediasi).

Populasi dalam penelitian ini adalah semua perusahaan yang sudah go public dan yang terdaftar di Bursa Efek Indonesia (BEI) yang tergabung dalam indeks Saham LQ45 untuk periode 2012 - 2015. Berdasarkan data yang diperoleh dari Indonesia Capital Market Directory (ICMD), diketahui bahwa jumlah perusahaan yang terdaftar sebanyak 45 perusahaan.

Sampel dalam penelitian ini Perusahaan yang terdaftar dalam indeks saham ini sebanyak 45 perusahaan, namun dengan kriteria tertentu pada akhirnya didapat sebanyak 25 perusahaan yang memenuhi syarat penelitian untuk dijadikan sampel. Jenis data yang digunakan dalam penelitian ini yaitu data kuantitatif, yaitu data yang berupa kumpulan dari data angka-angka. Sedangkan sumber data menggunakan data sekunder yaitu data yang berasal dari pengolahan oleh pihak lain yang berupa laporan keuangan dan rasio keuangan perusahaan-perusahaan yang tergabung dalam indeks saham LQ45 di Bursa Efek Indonesia periode 2012 - 2015 dari berbagai macam sektor non Bank. Teknik pengumpulan data yang dijadikan obyek penelitian berasal dari data sekunder yang diambil dari bukan dari sumber utama (perusahaan) yaitu dengan cara mengunduh data di website www.idx.co.id. merupakan teknik pengumpulan data dengan cara dokumentasi. Data-data yang telah dikumpulkan lalu diolah menggunakan e-Views versi 9. Analisis data yang digunakan untuk menguji hipotesis dalam penelitian ini adalah menggunakan analisis data kuantitatif, yaitu analisis data yang menggunakan data yang berbentuk angka-angka yang diperoleh dari hasil pengukuran dan penjumlahan. Model analisa regresi dengan menggunakan data panel dapat dilakukan melalui tiga teknik pendekatan, antara lain:

\section{Common Effect Model (CEM)}

Model Common Effect sama seperti OLS dengan meminimumkan jumlah kuadrat, tetapi data yang digunakan bukan data time series atau data cross section 
saja melainkan data panel yang diterapkan dalam bentuk pooled. Bentuk untuk model Ordinary Least Square adalah:

$Y_{\mathrm{it}}=b_{0}+b_{1} X_{i t}+b_{2} X_{i t}+\varepsilon_{i t}$

untuk $i=1,2, \ldots, \mathrm{n}$

dan $\mathrm{t}=1,2, \ldots, \mathrm{t}$

\section{Fixed Effect Model (FEM)}

Teknik model Fixed Effect adalah teknik mengestimasi data panel dengan menggunakan variabel dummy untuk menangkap adanya perbedaan intersep. Pendekatan dengan variabel dummy ini dikenal dengan sebutan Fixed Effect Model atau Least Square Dummy Variabel (LSDV) atau disebut juga Covariance Model. Persamaan pada estimasi dengan menggunakan Fixed Effect Model dapat ditulis dalam bentuk sebagai berikut:

$Y_{\mathrm{it}}=b_{0}+b_{1} X_{i t}+b_{2} X_{i t}+b_{3} D_{1 i}+b_{4} D_{2 i}+\ldots \ldots+\varepsilon_{i t}$

Dimana:

$$
\begin{aligned}
& i=1,2, \ldots, \mathrm{n} \\
& t=1,2, \ldots, \mathrm{t} \\
& D=\text { dummy }
\end{aligned}
$$

\section{Random Effect Model (REM)}

Random Effect Model adalah model estimasi regresi panel dengan asumsi koefesien slope kontan dan intersep berbeda antara individu dan antar waktu (Random Effect).

Model yang tepat digunakan untuk mengestimasi Random Effect adalah Generalized Least Square (GLS) sebagai estimatornya, karena dapat meningkatkan efesiensi dari least square. Bentuk umum untuk Random Effect adalah:

Yit $=\alpha 1+b j X j i t+\varepsilon i t$ dengan $\varepsilon i t=u i+v t+w i t$

\section{Dimana :}

$u i \sim N(0, \delta u 2)=$ komponen cross section error

$v t \sim N(0, \delta v 2)=$ komponen time series error

wit $\sim N(0, \delta w 2)=$ komponen eror kombinasi

Tahapan untuk memutuskan model regresi data panel yang tepat adalah sebagai berikut:

- Analisa dengan Common Effect Model;

- Analisa dengan Fixed Effect Model;

- Uji F Restricted (Chow Test), pengujian Common Effect vs Fixed Effect, yaitu:

a. Jika $\mathrm{H}_{0}$ diterima, maka model Common Effect dan selesai sampai disini.

b. Jika $\mathrm{H}_{0}$ ditolak, maka model Fixed Effect dan lanjutkan ke tahap berikutnya;

Uji Chow ialah pengujian untuk menentukan model Fixed Effect atau Common Effect yang lebih tepat digunakan dalam mengestimasi data panel. Dasar penolakan terhadap hipotesis di atas adalah dengan membandingkan perhitungan $\mathrm{F}$ statistik dengan F tabel. Perbandingan dipakai apabila hasil F hitung lebih besar (>) dari $\mathrm{F}$ tabel, maka $\mathrm{H}_{0}$ ditolak yang berarti model yang lebih tepat digunakan adalah 
Analisis Pengaruh Rasio Likuiditas, Solvabilitas, Profitabilitas, dan Aktivitas terhadap Nilai Perusahaan pada Perusahaan yang Tergabung dalam Indeks Lq45 di Bursa Efek Indonesia Periode 2012 - 2015

Fixed Effect Model. Begitupun sebaliknya, jika F hitung lebih kecil $(<)$ dari F tabel, maka $\mathrm{H}_{0}$ diterima dan model yang lebih tepat digunakan adalah Common Effect Model.

1. Analisa dengan Random Effect Model;

2. Uji Hausman (Random Effect vs Fixed Effect), yaitu:

3. Uji Langrange Multiplier (LM).

\section{Hasil dan Pembahasan}

Price to Book Value (PBV) dan variable independent meliputi Curent Ratio (CR), Debt to Equity Ratio (DER), Return on Asset (ROA), Total Asset Turnover (TATO) dan Price Earning Ratio (PER). Hasil deskripsi disampaikan dalam Tabel dibawah ini:

\section{Tabel 1}

Statistik Deskriptif Variabel Penelitian

\begin{tabular}{lcccccc}
\hline & PBV & CR & Der & ROA & TATO & PER \\
\hline Mean & 4,66 & 2,35 & 0,88 & 0,32 & 0,83 & 16,34 \\
\hline Medium & 2,82 & 1,9 & 0,66 & 0,11 & 0,7 & 15,59 \\
\hline Maximum & 58,48 & 9,71 & 3,56 & 9,97 & 2,32 & 48,24 \\
\hline Minimum & 0,02 & 0,42 & 0,15 & $-0,01$ & 0,15 & $-91,05$ \\
\hline Std Dev & 9,06 & 1,69 & 0,62 & 1,19 & 0,52 & 15,92 \\
\hline \multicolumn{1}{l}{ Observations } & 100 & 100 & 100 & 100 & 100 & 100 \\
\hline $\begin{array}{l}\text { Cross } \\
\text { Selections }\end{array}$ & 25 & 25 & 25 & 25 & 25 & 25 \\
\hline
\end{tabular}

Sumber: output data eviews tahun 2016

Tabel menunjukkan bahwa data yang digunakan dalam penelitian masingmasing berjumlah 100 data. Variabel Nilai Perusahaan dalam hal ini Price to Book Value (PBV) memiliki nilai rata-rata 4,66 dan nilai tengah 2,82. Untuk nilai maksimum 58,48 yaitu terdapat pada PT Unilever Indonesia Tbk tahun 2015, sedangkan nilai minimum sebesar 0,02 terdapat pada PT Astra Agro Lestari Tbk ahun 2015. Standar deviasi untuk PBV sebesar 9,06.

Variabel Current Ratio (CR) Perusahaan yang terdaftar di saham LQ45 mempunyai nilai rata-rata sebesar 2,35, sementara nilai tengah sebesar 1,89 terdapat pada PT Semen Indonesia Tbk tahun 2013. Nilai Maksimum sebesar 9,71 terdapat pada PT Media Nusantara Citra Tbk tahun 2014. Sedangkan nilai Minimum sebesar 0,41 berada pada PT XL Axiata Tbk tahun 2012. Untuk Standar Deviasi Current Ratio sebesar 1,69. Current Ratio digunakan untuk mengukur kemampuan perusahaan dalam membayar kewajiban jangka pendeknya dengan menggunakan aktiva lancar yang dimiliki perusahaan. Tetapi suatu perusahaan dengan current ratio yang tinggi belum tentu menjamin akan dapat dibayarnya hutang perusahaan yang sudah jatuh tempo karena proporsi atau distribusi dari aktiva lancar yang tidak menguntungkan, misalnya jumlah persediaan yang relatif tinggi dibandingkan taksiran tingkat penjualan yang akan 
datang sehingga tingkat perputaran persediaan rendah dan menunjukkan adanya over interstment dalam persediaan tersebut atau adanya saldo piutang yang besar yang mungkin sulit untuk ditagih.

Variabel Debt to Equity Ratio (DER) mempunyai nilai rata-rata sebesar 0,88. Untuk nilai tengahnya sebesar 0,66. Nilai maksimum sebesar 3,56 terdapat pada PT XL Axiata tahun 2014, sedangkan nilai minimum sebesar 0,16 yaitu pada PT Indocement Tunggal Prakarsa tahun 2013 dan 2015. Standar deviasi Debt to Equity Ratio sebesar 0,62. Rasio ini digunakan para analis dan para investor untuk melihat seberapa besar hutang perusahaan jika dibandingkan ekuitas yang dimiliki oleh perusahaan atau para pemegang saham. DER dengan angka dibawah 1,00, mengindakasikan bahwa perusahaan memiliki hutang yang lebih kecil dari ekuitas yang dimilikinya.

Variabel Return on Assets (ROA) mempunyai nilai rata-rata 0,32, sedangkan nilai tengahnya sebesar 0,1 . Untuk nilai maksimum sebesar 9,97 yaitu pada PT Global Mediacom Tbk tahun 2012. Untuk nilai minimum sebesar -0,01 yaitu pada PT XL Axiata Tbk tahun 2014 dan 2015. Standar Deviasi pada Return on Assets sebesar 1,19. Return on Assets (ROA) menunjukkan keberhasilan perusahaan dalam menghasilkan keuntungan. ROA mampu mengukur kemampuan perusahaan manghasilkan keuntungan pada masa lampau untuk kemudian diproyeksikan di masa yang akan datang. Assets atau aktiva yang dimaksud adalah keseluruhan harta perusahaan, yang diperoleh dari modal sendiri maupun dari modal asing yang telah diubah perusahaan menjadi aktivaaktiva perusahaan yang digunakan untuk kelangsungan hidup perusahaan.

Variabel Total Assets Turnover (TATO) mempunyai nilai rata-rata sebesar 0,83, sedangkan nilai tengah sebesar 0,70 . Untuk nilai maksimum sebesar 2,32 yaitu terdapat pada PT Unilever Tbk tahun 2015. Sedangkan untuk nilai minimum sebesar 0,15 terdapat pada PT Alam Sutra Realty Tbk tahun 2015. Untuk standar deviasi Total Assets Turnover sebesar 0,52. Total assets Turnover mengukur intensitas perusahaan dalam menggunakan aktivanya. Ukuran penggunaan aktiva paling relevan adalah penjualan, karena penjualan penting bagi laba. merupakan rasio antara jumlah aktiva yang digunakan dengan jumlah penjualan yang diperoleh selama periode tertentu. Rasio ini merupakan ukuran sampai seberapa jauh aktiva telah dipergunakan dalam kegiatan perusahaan atau menunjukan berapa kali aktiva berputar dalam periode tertentu. Apabila dalam menganalisis rasio ini selama beberapa periode menunjukan suatu trend yang cenderung meningkat, memberikan gambaran bahwa semakin efisiensi penggunaan aktiva sehingga hasil usaha akan meningkat.

Variabel Price Earning Ratio (PER) mempunyai nilai rata-rata sebesar 16,34, sedangkan nilai tengah sebesar 15,59. Untuk nilai maksimum sebesar 48,24 yaitu terdapat pada PT Unilever Tbk tahun 2015. Sedangkan untuk nilai minimum sebesar 91,05 terdapat pada PT Global Mediacom Tbk tahun 2015. Untuk standar deviasi sebesar 15,92. Price Earning Ratio (PER) adalah salah satu ukuran paling dasar dalam analisis saham secara fundamental. Perusahaan dengan peluang tingkat pertumbuhan tinggi biasanya mempunyai Price Earning Ratio yang tinggi pula, dan hal ini menunjukkan bahwa pasar mengharapkan pertumbuhan laba di masa mendatang. 
Analisis Pengaruh Rasio Likuiditas, Solvabilitas, Profitabilitas, dan Aktivitas terhadap Nilai Perusahaan pada Perusahaan yang Tergabung dalam Indeks Lq45 di Bursa Efek Indonesia Periode 2012 - 2015

Sebaliknya perusahaan dengan tingkat pertumbuhan yang rendah cenderung mempunyai Price Earning Ratio yang rendah pula. Semakin rendah Price Earning Ratio suatu saham maka semakin baik atau murah harganya untuk diinvestasikan.

1) Analisa dengan Common Effect Model:

\section{Tabel 2}

Common Effect Model

\begin{tabular}{lcccc}
\hline \multicolumn{1}{c}{ Variabel } & coefficient & Std Error & t-Statistic & Prob \\
\hline CR? & $-1,089678$ & 0,349006 & $-3,122803$ & 0,00224 \\
DER? & 1,668253 & 0,940135 & 1,774482 & 0,0792 \\
ROA? & 0,344898 & 0,606336 & 0,568824 & 0,5708 \\
TATO ? & 6,786977 & 1,263255 & 5,372611 & 0.0000 \\
PER & 0,063024 & 0,048446 & 1,300912 & 0,1964 \\
\hline R-squered & 0,41213 & Mean dependent var & 4,664446 \\
Adjusment R-Squer & 0,387378 & S.D dependent var & 9,064448 \\
S.E of Regresion & 7,09476 & Akaike info criterion & 6,805297 \\
Sun squered resid & 4781884 & Schwarz criterion & 6,935555 \\
log likelhood & $-335,2648$ & Hannan-Quinn Criter & 6,858015 \\
Durbin- Watson star & 0,130019 & & & \\
\hline
\end{tabular}

Sumber: output data eviews tahun 2016

Dari hasil pengujian Common Effect Model pada tabel diatas, diketahui bahwa hanya variabel Total Assets Turnover (TATO) yang signifikan dengan koefisien sebesar 6,78 dengan probabilitas sebesar 0,0000. Ini berarti bahwa probabilitas variabel tersebut lebih lebih kecil dari nilai $\alpha(0,05)$ atau signifikan. Sedangkan keempat variabel lainnya mempunyai tingkat probabilitas lebih besar dari nilai $\alpha$ $(0,05)$ atau tidak signifikan.

2) Analisa dengan Fixed Effect Model;

Tabel 3

Fixed Effect Model

\begin{tabular}{lrrrr}
\hline Variable & Coefficient & \multicolumn{1}{c}{ Std Error } & t-Statitic & \multicolumn{1}{l}{ Prob } \\
\hline C & $-0,176534$ & 2,224824 & $-0,079347$ & 0,937 \\
\hline CR? & 0,167175 & 0,284526 & 0,587557 & 0,5587 \\
\hline DER? & 0,633877 & 0,852351 & 0,743681 & 0,4596 \\
\hline ROA? & $-0,16225$ & 0,314478 & $-0,515864$ & 0,6076 \\
\hline TATO? & 4,278489 & 2.051 .993 & 2,065041 & 0,0407 \\
\hline PER? & 0,024028 & 0,017573 & 1,367316 & 0,1769 \\
\hline Fixed Effect (Cross & & & & \\
\hline _AAU_C & $-3,720136$ & & & \\
\hline _ADRO_C & $-2,655962$ & & & \\
\hline _AKRA_C & $-4,713627$ & & & \\
\hline _ASII_C & $-2,163019$ & & & \\
\hline _ASRI_C & $-0,424729$ & & & \\
\hline _BMTR_C & $-0,032858$ & & & \\
\hline _CPIN_C & $-2,271243$ & & & \\
\hline
\end{tabular}




\begin{tabular}{|c|c|c|c|}
\hline EXCL_C & $-2,542323$ & & \\
\hline GGRM_C & $-1,737066$ & & \\
\hline ICBP_C & $-2,982244$ & & \\
\hline INDF_C & 0,014326 & & \\
\hline INTP_C & $-4,674979$ & & \\
\hline ITMG_C & 0,88215 & & \\
\hline JSMR_C & $-0,00931$ & & \\
\hline KLBF_C & $-1,541916$ & & \\
\hline LPKR_C & $-1,073135$ & & \\
\hline MNCN_C & 0,217966 & & \\
\hline PGAS_C & $-0,131679$ & & \\
\hline PTBA_C & $-1,816014$ & & \\
\hline SMGR_C & $-0,1119435$ & & \\
\hline TLKM_C & $-0,408435$ & & \\
\hline INTR_C & $-2,889362$ & & \\
\hline _UNVR_C & 35,71088 & & \\
\hline \multicolumn{4}{|c|}{ Effects Spesiffication } \\
\hline \multicolumn{4}{|c|}{ Cross-Section fixed (dummy Variable) } \\
\hline R-squred & 0,973454 & Mean dependent var & 4,664446 \\
\hline $\begin{array}{l}\text { Adjusted R- } \\
\text { Squred }\end{array}$ & 0,962457 & S.D dependent var & 9,05448 \\
\hline S.E of regresion & 1,766338 & Akaka indo orriention & 4,207664 \\
\hline Sum squer Resid & 215,9307 & Schwarz criterion & 4,939215 \\
\hline Log Likeedhood & $-180,3832$ & Hannan Quinn criter & 4,523972 \\
\hline F-statistic & 86,51546 & Durbin-Watson Staf & 1,88721 \\
\hline Frob(F-statistic) & 0.00000 & & \\
\hline
\end{tabular}

Pada Tabel di atas diketahui bahwa probabilitas dari kelima variabel yaitu Current Ratio (CR), Debt to Equity Ratio (DER), Return on Assets (ROA), Total Assets Turnover (TATO) dan Price Earning Ratio (PER) yang mempunyai tingkat probabilitas yang lebih besar dari nilai $\alpha(0,05)$ atau tidak signifikan adalah variabel CR, DER, ROA dan PER. Sedangkan variabel TATO mempunyai probabilitas sebesar 0,04 yaitu lebih rendah dari nilai $\alpha(0,05)$ atau signifikan.

Dari hasil analisa tersebut dapat diperoleh bahwa secara umum nilai Current Ratio $(\mathrm{CR})$ berpengaruh positif tidak signifikan (koefisien $=0.167175$ ) terhadap Price to Book Value (PBV) dengan P-value 0.000, artinya bahwa kenaikan $1 \%$ pada Current Ratio akan meningkatkan $16,71 \%$ PBV. Demikian pula dengan nilai Debt to Equity Ratio (DER) berpengaruh positif tidak signifikan (koefisien $=0.633877$ ) terhadap Price to Book Value (PBV) dengan P-value 0.000, artinya kenaikan $1 \%$ DER akan meningkatkan 63,38\% PBV. Untuk variabel Return On Assets (ROA) berpengaruh negatif tidak signifikan (koefisien $=-0.162225$ ) terhadap Price to Book Value (PBV) dengan P-value 0.000, artinya bahwa kenaikan $1 \%$ pada Return On Assets akan menurunkan -16\% PBV. Untuk nilai Total Assets Turnover (TATO) berpengaruh positif sigmifikan (koefisien $=4.278489$ ) terhadap Price to Book Value (PBV) dengan P-value 0.000, artinya bahwa kenaikan 1\% pada Total Assets Turnover (TATO) akan meningkatkan 427,84\% PBV. Pada variabel Price Earning 
Analisis Pengaruh Rasio Likuiditas, Solvabilitas, Profitabilitas, dan Aktivitas terhadap Nilai Perusahaan pada Perusahaan yang Tergabung dalam Indeks Lq45 di Bursa Efek Indonesia Periode 2012 - 2015

Ratio (PER), nilai yang didapat berpengaruh positif tidak signifikan (koefisien = 0.024028) terhadap Price to Book Value (PBV) dengan P-value 0.000, artinya bahwa kenaikan 1\% pada Price Earning Ratio akan meningkatkan 2,40\% PBV. Sedangkan Nilai Adjusted R-square sebesar 96.2\%.

a. Uji F Restricted atau Uji Chow (Common Effect vs Fixed Effect)

\section{Tabel 4}

\section{Uji Chow}

\begin{tabular}{|c|c|c|c|c|}
\hline Effects Test & & Statistic & d.f & Prob \\
\hline Cross Section F & & 44.440 .808 & $(24.70)$ & 0.0000 \\
\hline cross Section Chi Squer & & 278.728 .325 & 24 & 0.0000 \\
\hline \multicolumn{5}{|c|}{ Cross Section Fread effects test equition } \\
\hline \multicolumn{5}{|c|}{ Dependent Variable PBV? } \\
\hline \multicolumn{5}{|c|}{ Method Parsial Least Squer } \\
\hline \multicolumn{5}{|c|}{ Date $05 / 12 / 2016$ time $11: 41$} \\
\hline \multicolumn{5}{|c|}{ Sample 20122015} \\
\hline \multicolumn{5}{|l|}{ Include observations :4 } \\
\hline \multicolumn{5}{|c|}{ Cross Sections include: 25} \\
\hline \multicolumn{5}{|c|}{ total pool (ballance) observations :100 } \\
\hline Variable & Coeffition & Std. Error & $\mathrm{t}$-Statisric & Prob \\
\hline $\mathrm{C}$ & $-12,57707$ & 2,150423 & $-5,83861$ & 0.0000 \\
\hline CR? & 0,678274 & 0,426207 & 1,591416 & 0,1149 \\
\hline DER? & 5,9963338 & 1,096608 & 0,426207 & 0.0000 \\
\hline ROA & 0,553456 & 0,523166 & 1,067918 & 0,2926 \\
\hline TATO & 10,9016 & 1,296152 & 8,417236 & 0.0000 \\
\hline PER? & 0,070263 & 0,041721 & 1,684101 & 0,0955 \\
\hline R-squered & 0,558979 & \multicolumn{2}{|c|}{ Mean dependent var } & 4,664446 \\
\hline Adjusment r-squered & 0,540053 & \multicolumn{2}{|c|}{ S.D dependent var } & 9,064446 \\
\hline S.E of regresion & 6,17228 & \multicolumn{2}{|c|}{ Akaka indo orriention } & 6,514948 \\
\hline Sum Squered Resid & 3506,034 & \multicolumn{2}{|c|}{ Schwarz criterion } & 6,671258 \\
\hline Log likelhood & $-319,7474$ & \multicolumn{2}{|c|}{ Hannan Quinn criter } & 6,578209 \\
\hline F-statistic & 24,51739 & \multicolumn{2}{|c|}{ Durbin-Watson Staf } & 0.202712 \\
\hline Prob(F-statistic) & 0.00000 & & & \\
\hline
\end{tabular}

Sumber: output data eviews tahun 2016

Berdasarkan hasil Uji Chow yang ditunjukkan pada Tabel 5.4 Nilai probabilitas signifikansi pada model persamaan tersebut di atas 0,0000 dan $\mathrm{F}$ hitung $(44,440)>\mathrm{F}$ tabel (nilai $\alpha=0,05$ ) maka $\mathrm{H}_{0}$ diterima dan model yang terpilih adalah Fixed Effect. Setelah model Fixed Effect terpilih, maka perlu melakukan Analisa Random Effect. 
Bistok Simorangkir dan Nunung Nurhasanah

b. Analisa dengan Random Effect Model

Tabel 5

Random Effect Model

\begin{tabular}{|c|c|c|c|c|}
\hline Variable & Coefficient & Std Error & t-Statitic & Prob \\
\hline $\mathrm{C}$ & $-3,741273$ & 2,165454 & 1,727701 & 0,0873 \\
\hline $\mathrm{CR} ?$ & 0,139861 & 0,269628 & 0,518874 & 0,6061 \\
\hline DER? & 1,668756 & 0,776063 & 2,15027 & 0,0341 \\
\hline ROA? & $-0,192624$ & 0,301822 & $-0,633628$ & 0,5246 \\
\hline TATO? & 7,400167 & 2.051 .993 & 2,065041 & 0,0407 \\
\hline PER? & 0,032305 & 0,01688 & 1,902461 & 0,0602 \\
\hline \multicolumn{5}{|c|}{ Random Efects } \\
\hline _AALI_C & $-3,185948$ & & & \\
\hline _ADRO_C & $-1,716716$ & & & \\
\hline _AKRA_C & $-7,555411$ & & & \\
\hline _ASII_C & $-2,418072$ & & & \\
\hline _ASRI_C & 0,726544 & & & \\
\hline _BMTR_C & 1,78114 & & & \\
\hline _BSDE_C & 2,143392 & & & \\
\hline _CPIN_C & $-4,183487$ & & & \\
\hline _EXCL_C & $-1,189811$ & & & \\
\hline _GGRM_C & $-3,246613$ & & & \\
\hline _ICBP_C & $-2,613118$ & & & \\
\hline _INDF_C & $-2,830459$ & & & \\
\hline _INTP_C & 1,534536 & & & \\
\hline _ITMG_C & -6.178 .881 & & & \\
\hline _JSMR_C & 1,763034 & & & \\
\hline _KLBF_C & $-1,241197$ & & & \\
\hline _LPKR_C & 0,01216 & & & \\
\hline _MNCN_C & 0,583997 & & & \\
\hline _PGAS_C & 0,63418 & & & \\
\hline _PTBA_C & $-1,681618$ & & & \\
\hline _SMGR_C & 0,549449 & & & \\
\hline _TLKM_C & 0,250128 & & & \\
\hline _INTR_C & $-2,793196$ & & & \\
\hline _UNVR_C & 29,03373 & & & \\
\hline
\end{tabular}

Effects Spesiffication

\begin{tabular}{|c|c|c|c|}
\hline \multicolumn{2}{|c|}{ 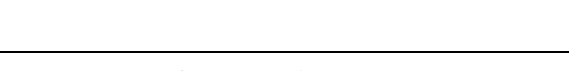 } & $8 \mathrm{D}$ & Rng \\
\hline \multicolumn{2}{|c|}{ Cross Section random } & 6,076707 & 0,9229 \\
\hline \multicolumn{2}{|c|}{ Indentificationtic eandom } & 1,756338 & 0,0771 \\
\hline R-squred & 0,2123292 & Mean dependent var & 0,667147 \\
\hline Adjusted R-Squred & 0,171446 & 8.D dependent var & 2,005865 \\
\hline S.E of regresion & 1,826836 & Sum squared resid & 213,2262 \\
\hline F-statistic & 9,097042 & Durbin-Watson Staf & 1,370907 \\
\hline Frob(F-statistic) & 0,000363 & & \\
\hline
\end{tabular}


Analisis Pengaruh Rasio Likuiditas, Solvabilitas, Profitabilitas, dan Aktivitas terhadap Nilai Perusahaan pada Perusahaan yang Tergabung dalam Indeks Lq45 di Bursa Efek Indonesia Periode 2012 - 2015

\begin{tabular}{lrcr}
\hline Unweiginies 8 statistic & & & \\
\hline R-squred & 0,443621 & Mean opration Var & 4,664446 \\
sum Squared resid & 4526540 & Durbin-Watson Staf & 0,094906 \\
\hline
\end{tabular}

Sumber: output data eviews tahun 2016

Berdasarkan Tabel di atas diketahui bahwa pada model Random Effect terdapat dua variabel yang probabilitasnya lebih rendah dari nilai $\alpha(0,05)$ atau signifikan yaitu variabel DER sebesar 0,03 dan TATO sebesar 0,000. Ketiga variabel lainnya mempunyai nilai yang lebih besar dari nilai $\alpha(0,05)$ atau tidak signifikan.

Dari hasil analisa tersebut diperoleh bahwa secara umum nilai Current Ratio $(\mathrm{CR})$ berpengaruh positif tidak signifikan (koefisien $=0.139851$ ) terhadap nilai Price to Book Value (PBV) dengan P-value 0.000, artinya bahwa kenaikan $1 \%$ pada nilai Current Ratio akan meningkatkan 13,98\% PBV. Demikian pula dengan nilai Debt to Equity Ratio (DER) berpengaruh positif signifikan (koefisien $=1.668756)$ terhadap nilai Price to Book Value $(\mathrm{PBV})$ dengan Pvalue 0.000 , artinya kenaikan $1 \%$ DER akan meningkatkan $166,87 \%$ PBV. Nilai Return on Assets (ROA) berpengaruh negatif tidak signifikan (koefisien = 0.192624) terhadap nilai Price to Book Value (PBV) dengan P-value 0.000, artinya bahwa kenaikan $1 \%$ pada nilai Return On Assets akan menurunkan 19,26\% PBV. Nilai Total Assets Turnover (TATO) berpengaruh positif signifikan (koefisien $=7.403167$ ) terhadap nilai Price to Book Value (PBV) dengan P-value 0.000 , artinya bahwa kenaikan $1 \%$ pada nilai Total Assets Turnover akan meningkatkan 740,31\% PBV. Sedangkan nilai Price Earning Ratio $(\mathrm{PER})$ berpengaruh positif tidak signifikan (koefisien $=0.032305$ ) terhadap nilai Price to Book Value (PBV) dengan P-value 0.000, artinya bahwa kenaikan $1 \%$ pada nilai Price Earning Ratio akan meningkatkan 3,23\% PBV. Nilai Intersep (C) -3.741273 merupakan nilai rata-rata dari komponen kesalahan random (random error component

\section{B. Pembahasan}

Hasil penelitian ini menyatakan bahwa pengujian secara parsial terhadap variabel-variabel independen seperti Current Ratio, Debt to Equity Ratio, Return on Assets, Total Assets Turnover dan Price Earning Ratio terhadap variabel dependen Price to Book Value dengan uraian sebagai berikut:

\section{Pengaruh Current Ratio terhadap Price to Book Value}

Hasil penelitian menyimpulkan bahwa Current Ratio berpengaruh positif tidak signifikan terhadap Nilai Perusahaan (Price to Book Value) dikarenakan mempunyai nilai probabilitas yang tidak signifikan yaitu lebih besar dari nilai $\alpha$ $(0,05)$. Hasil ini sesuai dengan penelitian yang telah dilakukan oleh (Dj, Artini, \& Suarjaya, 2010). Nilai ini mengindikasikan bahwa likuiditas tidak terlalu dipertimbangkan oleh pihak eksternal perusahaan dalam melakukan penilaian 
sebuah perusahaan dan tidak memiliki pengaruh yang signifikan terhadap perubahan harga saham sebuah perusahaan.

\section{Pengaruh Debt to Equity Ratio terhadap Price to Book Value}

Hasil penelitian menyimpulkan bahwa Debt to Equity Ratio berpengaruh positif tidak signifikan terhadap Nilai Perusahaan (Price to Book Value) karena nilai probabilitasnnya lebih besar dari nilai $\alpha(0,05)$ atau idak signifikan. Hasil ini sejalan dengan penelitian (Mardiyati, 2010) bahwa kebijakan hutang berpengaruh positif tetapi tidak signifikan terhadap nilai perusahaan. Hal ini terjadi dikarenakan adanya agency problem dimana muncul antara kreditur (pemberihutang), contohnya pemegang obligasi perusahaan (bondholders) dengan pemegang saham (stockholders) yang diwakili oleh manajemen perusahaan. Konflik tersebut muncul karena manajemen mengambil proyekproyek yang resikonya lebih besar daripada yang diperkirakan oleh kreditur atau karena perusahaan meningkatkan jumlah hutang hingga mencapai tingkatan yang lebih tinggi daripada yang diperkirakan kreditor.

\section{Pengaruh Return Of Assets terhadap Price to Book Value}

Dapat ditarik kesimpulan bahwa Return on Assets berpengaruh negatif tidak signifikan terhadap Nilai Perusahaan (Price to Book Value)) karena nilai probabilitasnnya sebesar sebesar -0,162225 lebih kecil dari nilai $\alpha(0,05)$ atau tidak signifikan.. Penelitian ini sejalan dengan penelitian oleh Herawati (2012). Hal ini berarti bahwa apabila profitabilitas perusahaan meningkat, maka nilai perusahaan akan mengalami penurunan. Hal ini dikarenakan oleh peningkatan profitabilitas perusahaan akan menjadikan laba per lembar saham perusahaan meningkat, tetapi dengan peningkatan profitabilitas belum tentu harga saham perusahaan akan meningkat sehingga apabila laba per lembar saham meningkat tetapi harga saham tidak meningkat maka hal tersebut membuat nilai perusahaan menurun.

\section{Pengaruh Total Assets Turnover terhadap Price to Book Value}

Hasil penelitian di atas dapat disimpulkan bahwa Total Assets Turnover berpengaruh positif dan signifikan terhadap Nilai Perusahaan (Price to Book Value) karena nilai probabilitasnnya sebesar $0,0407<$ nilai $\alpha(0,05)$ Hal ini sejalan dengan penelitian oleh Alivia dan Chabachib (2013) menyimpulkan bahwa Total Asset Turnover berpengaruh positif signifikan terhadap Nilai Perusahaan (Price Book Value). Semakin tinggi Total Asset Turnover (TATO) maka kemampuan perusahaan dalam mengelola aktiva menjadi semakin efisien. Jika aktiva perusahaan dikelola secara efektif dan efisien maka kinerja serta nilai perusahaan menjadi semakin baik.

\section{Pengaruh Price Earning Ratio terhadap Price to Book Value}

Hasil penelitian menyimpulkan bahwa Price Earning Ratio tidak berpengaruh secara signifikan terhadap Nilai Perusahaan (Price to Book Value) perusahaan yang terdaftar pada saham LQ45 periode 2012 - 2015 karena nilai probabilitasnya lebih besar dari nilai $\alpha(0,05)$. Hal ini sesuai dengan penelitian 
Analisis Pengaruh Rasio Likuiditas, Solvabilitas, Profitabilitas, dan Aktivitas terhadap Nilai Perusahaan pada Perusahaan yang Tergabung dalam Indeks Lq45 di Bursa Efek Indonesia Periode 2012 - 2015

dari (Ang \& Choi, 1997) yang menyatakan bahwa Price Earning Ratio memiliki hubungan positif dengan harga saham, sehingga jika Price Earning Ratio meningkat maka harga saham juga akan semakin besarPrice to Book Value (PBV) dan variable independent meliputi Curent Ratio (CR), Debt to Equity Ratio (DER), Return on Asset (ROA), Total Asset Turnover (TATO) dan Price Earning Ratio (PER). Hasil deskripsi disampaikan dalam Tabel dibawah ini:

\section{Tabel 6}

Statistik Deskriptif Variabel Penelitian

\begin{tabular}{lcccccc}
\hline & PBV & CR & Der & ROA & TATO & PER \\
\hline Mean & 4,66 & 2,35 & 0,88 & 0,32 & 0,83 & 16,34 \\
\hline Medium & 2,82 & 1,9 & 0,66 & 0,11 & 0,7 & 15,59 \\
\hline Maximum & 58,48 & 9,71 & 3,56 & 9,97 & 2,32 & 48,24 \\
\hline Minimum & 0,02 & 0,42 & 0,15 & $-0,01$ & 0,15 & $-91,05$ \\
\hline Std Dev & 9,06 & 1,69 & 0,62 & 1,19 & 0,52 & 15,92 \\
\hline & & & & & & \\
\hline Observations & 100 & 100 & 100 & 100 & 100 & 100 \\
\hline Cross Selections & 25 & 25 & 25 & 25 & 25 & 25 \\
\hline
\end{tabular}

Sumber: output data eviews tahun 2016

Tabel menunjukkan bahwa data yang digunakan dalam penelitian masing-masing berjumlah 100 data. Variabel Nilai Perusahaan dalam hal ini Price to Book Value (PBV) memiliki nilai rata-rata 4,66 dan nilai tengah 2,82. Untuk nilai maksimum 58,48 yaitu terdapat pada PT Unilever Indonesia Tbk tahun 2015, sedangkan nilai minimum sebesar 0,02 terdapat pada PT Astra Agro Lestari Tbk ahun 2015. Standar deviasi untuk PBV sebesar 9,06.

Variabel Current Ratio (CR) Perusahaan yang terdaftar di saham LQ45 mempunyai nilai rata-rata sebesar 2,35, sementara nilai tengah sebesar 1,89 terdapat pada PT Semen Indonesia Tbk tahun 2013. Nilai Maksimum sebesar 9,71 terdapat pada PT Media Nusantara Citra Tbk tahun 2014. Sedangkan nilai Minimum sebesar 0,41 berada pada PT XL Axiata Tbk tahun 2012. Untuk Standar Deviasi Current Ratio sebesar 1,69. Current Ratio digunakan untuk mengukur kemampuan perusahaan dalam membayar kewajiban jangka pendeknya dengan menggunakan aktiva lancar yang dimiliki perusahaan. Tetapi suatu perusahaan dengan current ratio yang tinggi belum tentu menjamin akan dapat dibayarnya hutang perusahaan yang sudah jatuh tempo karena proporsi atau distribusi dari aktiva lancar yang tidak menguntungkan, misalnya jumlah persediaan yang relatif tinggi dibandingkan taksiran tingkat penjualan yang akan datang sehingga tingkat perputaran persediaan rendah dan menunjukkan adanya over interstment dalam persediaan tersebut atau adanya saldo piutang yang besar yang mungkin sulit untuk ditagih.

Variabel Debt to Equity Ratio (DER) mempunyai nilai rata-rata sebesar 0,88 . Untuk nilai tengahnya sebesar 0,66 . Nilai maksimum sebesar 3,56 terdapat pada PT XL Axiata tahun 2014, sedangkan nilai minimum sebesar 0,16 yaitu 
pada PT Indocement Tunggal Prakarsa tahun 2013 dan 2015. Standar deviasi Debt to Equity Ratio sebesar 0,62. Rasio ini digunakan para analis dan para investor untuk melihat seberapa besar hutang perusahaan jika dibandingkan ekuitas yang dimiliki oleh perusahaan atau para pemegang saham. DER dengan angka dibawah 1,00, mengindakasikan bahwa perusahaan memiliki hutang yang lebih kecil dari ekuitas yang dimilikinya.

Variabel Return on Assets (ROA) mempunyai nilai rata-rata 0,32, sedangkan nilai tengahnya sebesar 0,1 . Untuk nilai maksimum sebesar 9,97 yaitu pada PT Global Mediacom Tbk tahun 2012. Untuk nilai minimum sebesar -0,01 yaitu pada PT XL Axiata Tbk tahun 2014 dan 2015. Standar Deviasi pada Return on Assets sebesar 1,19. Return on Assets (ROA) menunjukkan keberhasilan perusahaan dalam menghasilkan keuntungan. ROA mampu mengukur kemampuan perusahaan manghasilkan keuntungan pada masa lampau untuk kemudian diproyeksikan di masa yang akan datang. Assets atau aktiva yang dimaksud adalah keseluruhan harta perusahaan, yang diperoleh dari modal sendiri maupun dari modal asing yang telah diubah perusahaan menjadi aktivaaktiva perusahaan yang digunakan untuk kelangsungan hidup perusahaan.

Variabel Total Assets Turnover (TATO) mempunyai nilai rata-rata sebesar 0,83, sedangkan nilai tengah sebesar 0,70. Untuk nilai maksimum sebesar 2,32 yaitu terdapat pada PT Unilever Tbk tahun 2015. Sedangkan untuk nilai minimum sebesar 0,15 terdapat pada PT Alam Sutra Realty Tbk tahun 2015. Untuk standar deviasi Total Assets Turnover sebesar 0,52. Total assets Turnover mengukur intensitas perusahaan dalam menggunakan aktivanya. Ukuran penggunaan aktiva paling relevan adalah penjualan, karena penjualan penting bagi laba. merupakan rasio antara jumlah aktiva yang digunakan dengan jumlah penjualan yang diperoleh selama periode tertentu. Rasio ini merupakan ukuran sampai seberapa jauh aktiva telah dipergunakan dalam kegiatan perusahaan atau menunjukan berapa kali aktiva berputar dalam periode tertentu. Apabila dalam menganalisis rasio ini selama beberapa periode menunjukan suatu trend yang cenderung meningkat, memberikan gambaran bahwa semakin efisiensi penggunaan aktiva sehingga hasil usaha akan meningkat.

Variabel Price Earning Ratio (PER) mempunyai nilai rata-rata sebesar 16,34, sedangkan nilai tengah sebesar 15,59. Untuk nilai maksimum sebesar 48,24 yaitu terdapat pada PT Unilever Tbk tahun 2015. Sedangkan untuk nilai minimum sebesar -91,05 terdapat pada PT Global Mediacom Tbk tahun 2015. Untuk standar deviasi sebesar 15,92. Price Earning Ratio (PER) adalah salah satu ukuran paling dasar dalam analisis saham secara fundamental. Perusahaan dengan peluang tingkat pertumbuhan tinggi biasanya mempunyai Price Earning Ratio yang tinggi pula, dan hal ini menunjukkan bahwa pasar mengharapkan pertumbuhan laba di masa mendatang. Sebaliknya perusahaan dengan tingkat pertumbuhan yang rendah cenderung mempunyai Price Earning Ratio yang 
Analisis Pengaruh Rasio Likuiditas, Solvabilitas, Profitabilitas, dan Aktivitas terhadap Nilai Perusahaan pada Perusahaan yang Tergabung dalam Indeks Lq45 di Bursa Efek Indonesia Periode 2012 - 2015

rendah pula. Semakin rendah Price Earning Ratio suatu saham maka semakin baik atau murah harganya untuk diinvestasikan.

\section{Kesimpulan}

Current Ratio tidak berpengaruh secara signifikan terhadap Nilai Perusahaan (Price to Book Value). Hasil ini sesuai dengan penelitian yang telah dilakukan oleh oleh Mahendra, ( $\mathrm{Dj}$ et al., 2010) bahwa Current Ratio (CR) tidak berpengaruh signifikan terhadap Price to Book Value. Hasil ini mengidikasikan bahwa, ukuran kemampuan perusahaan dalam memenuhi kewajiban-kewajibannya dengan tidak memperhitungkan persediaan, karena persediaan memerlukan waktu yang relatif lama untuk direalisasi menjadi uang kas, memberikan dampak pada peningkatan nilai perusahaan. Nilai perusahaan sangat penting karena dengan nilai perusahaan yang tinggi akan diikuti oleh tingginya kemakmuran pemegang saham (Brigham \& Houston, 2006).

Debt to Equity Ratio berpengaruh positif dan signifikan terhadap Nilai Perusahaan (Price to Book Value) sesuai dengan penelitian (Mardiyati, 2010). Bahwa kebijakan hutang berpengaruh positif tetapi tidak signifikan terhadap nilai perusahaan. bahwa kebijakan hutang berpengaruh positif tetapi tidak signifikan terhadap nilai perusahaan. Hal ini terjadi dikarenakan adanya agency problem dimana muncul antara kreditur (pemberi hutang),

contohnya pemegang obligasi perusahaan (bondholders) dengan pemegang saham (stockholders) yang diwakili oleh manajemen perusahaan. Konflik tersebut muncul karena manajemen mengambil proyek-proyek yang resikonya lebih besar daripada yang diperkirakan oleh kreditur atau karena perusahaan meningkatkan jumlah hutang hingga mencapai tingkatan yang lebih tinggi daripada yang diperkirakan kreditor.

Return on Assets berpengaruh negatif dan tidak signifikan terhadap Nilai Perusahaan (Price to Book Value) sesuai penelitian dari (Juwita \& Herawati, 2012). Kondisi ini mengidikasikan bahwa, ROA yang tinggi dapat memberikan dampak positif pada peningkatan nilai perusahaan. Hal ini sebagaimana fungsi dari ROA tersebut, yaitu untuk mengukur seberapa besar keuntungan yang diperoleh suatu perusahaan. Semakin besar keuntungan menunjukan semakin baik manajemen dalam pengelolaan suatu perusahaan.

Total Assets Turnover berpengaruh positif dan signifikan terhadap Nilai Perusahaan (Price to Book Value) sesuai penelitian dari (Alivia \& Chabachib, 2013). Rasio aktivitas ini melibatkan perbandingan antara tingkat penjualan dan investasi pada berbagai jenis aktiva. Sebaiknya terdapat keseimbangan yang layak antara penjualan dan berbagai unsur aktiva, yaitu persediaan, piutang, aktiva tetap, serta aktiva lain

Price Earning Ratio berpengaruh positif dan signifikan terhadap Nilai Perusahaan (Price to Book Value) sesuai dengan penelitian (Ang \& Choi, 1997) bahwa indikator perkembangan atau pertumbuhan perusahaan di masa yang akan datang (prospects of the firm). Semakin tinggi rasio PER, semakin tinggi pertumbuhan laba yang diharapkan oleh pemodal Rasio ini menunjukkan seberapa tinggi suatu saham 
dibeli oleh investor dibandingkan dengan laba per lembar saham. Price Earning Ratio memiliki hubungan positif dengan harga saham, sehingga jika Price Earning Ratio meningkat maka harga saham juga akan semakin besar.

\section{BIBLIOGRAFI}

Achmad, Komarudin, Subekti, Imam, \& Atmini, Sari. (2007). Investigasi motivasi dan strategi manajemen laba pada perusahaan publik di Indonesia. Jurnal Tema, 8(1). Google Scholar

Alivia, Natasha Rizky, \& Chabachib, M. (2013). Analisis Faktor-Faktor Yang Mempengaruhi Nilai Perusahaan Dengan Profitabilitas Sebagai Variabel Intervening (Studi Pada Perusahaan Manufaktur yang Listed di BEI Tahun 20082011). Fakultas Ekonomika dan Bisnis. Google Scholar

Ang, Beng W., \& Choi, Ki Hong. (1997). Decomposition of aggregate energy and gas emission intensities for industry: a refined Divisia index method. The Energy Journal, 18(3). Google Scholar

Brigham, Eugene F., \& Houston, Joel F. (2006). Fundamentals of financial management (Dasar-dasar Manajemen Keuangan). Jakarta: Salemba Empat. Google Scholar

Dj, Alfredo Mahendra, Artini, Luh Gede Sri, \& Suarjaya, A. A. Gede. (2010). Pengaruh kinerja keuangan terhadap nilai perusahaan pada perusahaan manufaktur di Bursa Efek Indonesia. Matrik: Jurnal Manajemen, Strategi Bisnis Dan Kewirausahaan. Google Scholar

Fama, Eugene F., \& French, Kenneth R. (1998). Value versus growth: The international evidence. The Journal of Finance, 53(6), 1975-1999. Google Scholar

Hasnawati, Sri. (2005). Implikasi Keputusan Investasi, Pendanaan, dan Dividen Terhadap Nilai Perusahaan Publik di Bursa Efek Jakarta. Usahawan: No, 9, 33-41. Google Scholar

Juwita, Cerlienia, \& Herawati, Juni. (2012). Pengaruh Variabel ROA, ROE, DER, EPS dan PER terhadap Return Saham Perusahaan Non Bank LQ45 Periode 2010-2012. Jurnal Ilmiah Mahasiswa FEB, 1(2). Google Scholar

Kusumadilaga, Rimba. (2010). Pengaruh corporate social responsibility terhadap nilai perusahaan dengan profitabilitas sebagai variabel moderating (Studi empiris pada perusahaan manufaktur yang terdaftar di Bursa Efek Indonesia). Perpustakaan FE UNDIP. Google Scholar

Mardiyati, Umi. (2010). dkk. 2012.“Analisis Pengaruh Kebijakan Dividen, Kebijakan 
Analisis Pengaruh Rasio Likuiditas, Solvabilitas, Profitabilitas, dan Aktivitas terhadap Nilai Perusahaan pada Perusahaan yang Tergabung dalam Indeks Lq45 di Bursa Efek Indonesia Periode 2012 - 2015

Hutang dan Profitabilitas Terhadap Nilai Perusahaan Pada Perusahaan Manufaktur Yang Terdaftar di Bursa Efek Indonesia Periode 2005-2010." Jurnal Riset Manajemen Sains Indonesia (JRMSI), 3(1). Google Scholar

Nurlela, Islahuddin. (2008). Pengaruh Corporate Social Responsibility Terhadap Nilai Perusahaan Dengan Prosentase Kepemilikan Manajemen Sebagai Variabel Moderating. Simposium Nasional Akuntansi XI, 3, 23-26. Google Scholar

Oktaviani, Rina, \& Puspitawati Haryadi, Eka. (2008). Impacts of ASEAN trade liberalization on ASEAN-6 economies and income distribution in Indonesia. ARTNeT Working Paper Series. Google Scholar

Samuel, Donna, Found, Pauline, \& Williams, Sharon J. (2015). How did the publication of the book The Machine That Changed The World change management thinking? Exploring 25 years of lean literature. International Journal of Operations \& Production Management. Google Scholar

Sudarma, Made. (2004). Pengaruh struktur kepemilikan saham, faktor intern dan faktor ekstern terhadap struktur modal dan nilai perusahaan. Universitas Brawijaya. Malang. Google Scholar

Susanti, Rika, \& Pangestuti, Irene Rini Demi. (2010). Analisis faktor-faktor yang berpengaruh terhadap nilai perusahaan (studi kasus pada perusahaan go public yang listed tahun 2005-2008). Universitas Diponegoro. Google Scholar

\section{Copyright holder:}

Bistok Simorangkir dan Nunung Nurhasanah (2021)

First publication right:

Journal Syntax Literate

This article is licensed under:

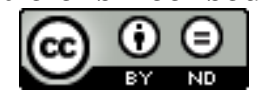

